\title{
Independent effects of habitat and stream typology on macroinverte- brate communities in Mediterranean-type intermittent streams
}

\author{
K. Sroczyńska1,2,*, F. Leitão ${ }^{3}$, I. Máximo ${ }^{3}$, P. Range ${ }^{4}$, A. Furtado ${ }^{5}$, M. Claro ${ }^{3}$ and L. Chícharo ${ }^{1}$ \\ ${ }^{1}$ Faculty of Science and Technology, Campus of Gambelas, University of Algarve 8005-139, Faro, Portugal. \\ 2 MARE-UE Marine and Environmental Sciences Centre, University of Évora, School of Sciences and Technol- \\ ogy, Biology Department, Apartado 94, 7002-554 Évora, Portugal \\ 3 Centro de Ciências do Mar, Universidade do Algarve, Campus de Gambelas 8005-139 Faro, Portugal. \\ ${ }^{4}$ Environmental Science Center (ESC), Qatar University, Doha, Qatar. \\ 5 APA-ARH, Algarve-Administração da região Hidrográfica do Algarve, I.P., Faro, Algarve, Portugal. \\ * Corresponding author: kasiasroczynska@gmail.com
}

Received: 21/08/17 Accepted: 25/05/18

\begin{abstract}
Independent effects of habitat and stream typology on macroinvertebrate communities in Mediterranean-type intermittent streams
\end{abstract}

Macroinvertebrate-based water quality assessment in temporary streams is an important yet still understudied issue. Investigating different aspects of macroinvertebrate distribution in these streams is therefore highly necessary for the successful implementation of bio-assessment programs. We investigated the variability in macroinvertebrate communities (number of families, abundance, taxonomic richness) and water quality index among six different habitat types (boulder, cobble, gravel, sand, macrophytes, particulate organic matter) and four stream typologies (medium-large southern rivers; southern mountainous rivers; small southern rivers; calcareous rivers). Samples were collected at 32 intermittent and 4 permanent sites in Mediterranean-type streams.

The structure of benthic communities showed differences among both habitats and typologies, but there was no interaction among these two factors, indicating that the effect of stream typology does not depend on the habitats that are present in the given stream type. Overall community structure was similar among mineral substrates and macrophytes, which was also reflected in low number of taxa with significant indicator values suggesting the prevalence of generalist tactic and low selectivity in terms of habitat partitioning at these temporary streams. Much higher number of indicator taxa was found for different stream typologies providing evidence that stream types are better predictor for taxa occurrences than a habitat unit at this scale. Southern mountainous streams hosted the highest number of families with significant Indicator Values suggesting that this typology is important for many families with less generalistic set of traits. This typology must be carefully addressed in monitoring programs for water quality assessment even at such fine scale. Further, we reported significant effects of Habitat and Typology for water quality index. Differences were particularly between gravel and organic or depositional habitats (macrophytes/sand/particulate organic matter). For the typology differences were observed between calcareous and non-calcareous stream types.

Key words: Algarve streams, IPtIs index, intermittent rivers, taxa assemblages, spatial scale

\section{RESUMO}

Efeitos independentes de tipologia e de habitat sobre comunidades de macroinvertebrados e índice de qualidade da água nas ribeiras intermitentes mediterrânicas

A avaliação da qualidade da água baseada em macroinvertebrados em ribeiras temporárias é uma questão importante, mas ainda pouco estudada. Investigar diferentes aspectos da ecologia de macroinvertebrados nestas ribeiras é, portanto, fundamental para a implementação de programas de bio-avaliação. No presente trabalho foi investigada a variabilidade nas métricas da comunidade de macroinvertebrados e índice de qualidade da água entre diferentes tipos de habitat (blocos, cascalho, gravilha, areia, macrófitos, matéria orgânica particulada) e tipologias das ribeiras mediterrânicas temporárias (Rios do 
Sul de Média-Grande Dimensão, Rios Montanhosos do Sul, Rios do Sul de Pequena Dimensão, Calcários do Algarve). A estrutura das comunidades bentónicas mostrou diferenças entre habitats e tipologias, mas não houve interacção entre estes dois factores, indicando que o efeito da tipologia não depende dos habitats que estão presentes neste tipo de ribeira. De forma geral, a estrutura da comunidade foi semelhante entre substratos minerais e macrófitos, reflectindo um baixo número de taxa com um valor indicador significativo, o que sugere a prevalência de uma tática generalista e baixa seletividade em termos de partição do habitat nestas ribeiras temporárias. Um maior número de taxa com potencial indicador foi encontrado para diferentes tipologias de ribeira, fornecendo evidências de que as tipologias são melhores preditores para ocorrências de espécies do que uma unidade de habitat nesta escala. Além disso, foram relatados efeitos significativos de Habitat e Tipologia para o indice de qualidade da água. As diferenças foram particularmente entre cascalho e os habitats orgânicos ou de deposição (macrófitos / areia / matéria orgânica particulada). Para a tipologia foram observadas diferenças entre calcárias e não calcárias. Devido às diferenças observadas no índice de qualidade da água entre habitats orgânicos e não orgânicos, a amostragem na escala de comprimento da ribeira deve incluir ambos os tipos de substrato.

Palavras chave: Ribeiras do Algarve, rios intermitentes, conjuntos de espécies, escala espacial, índice IPtIs

\section{INTRODUCTION}

The ecological assessment of intermittent rivers and streams using benthic macroinvertebrates is an unresolved issue, in particular in Mediterranean countries and, therefore, studies that approach different aspects of the implementation of macroinvertebrate based water quality indices are necessary (Stubbington et al., 2017). The main constrains of these indices are related to complex, multi-scale way that benthic macroinvertebrates respond to their environment (Johnson \& Hering, 2010). Macroinvertebrates possess very diverse traits and morphological adaptations that allow them to live in certain range of environmental conditions (Graça et al., 1989, Pires et al., 2000, Aguiar et al., 2002, Chaves et al., 2005). This is why they often display strong affinities for different substrates, oxygen concentrations and food resources (Cummins \& Lauff, 1967, Townsend \& Hildrew, 1994, Merrit \& Cummins, 1996, Pardo \& Armitage, 1997, Beisel et al., 1998, Chaves et al., 2005, Schröder et al., 2013, Southwood, 1977). Consequently, previous studies on structural dynamics of benthic fauna demonstrated strong influence of habitat characteristics on abundance, diversity and the trophic structure of macroinvertebrate assemblages (Pardo \& Armitage, 1997, Beisel et al., 2000, Brown, 2003, Bonada et al., 2006, Kubosova et al., 2010). The affinities displayed by certain groups of macroinvertebrates to particular areas of substrate prompted the use of habitat for better managing of stream biota (Armitage \& Pardo, 1995, Harper
\& Everard, 1998). For example, various studies found greater similarity in assemblages of different taxa within the same habitat types, among different sites, whereas, much lesser resemblance was found between fauna from different habitats, within one site (Angradi, 1996, Parsons \& Norris, 1996, Dallas, 2007, Rabeni, et al., 2002, Bonada et al., 2008). This multi-scale heterogeneity of macroinvertebrate distribution patterns causes the variation in biological metrics and water quality indices, which limits their comparability across the streams (Sánchez-Montoya et al., 2007, Sánchez-Montoya et al., 2009a, Sánchez-Montoya et al., 2010). In addition to habitat characteristics, stream typology is also an important determinant for adequate biological quality assessment (Verdonschot \& Nijboer, 2004). High variability in biotic metrics has been observed between mountainous and lowland streams with a strong influence of stream size and bottom substrate (Lorenz et al., 2004). Although these studies were conducted on a larger scale, a recent study provided evidence that macroinvertebrate distribution patterns are also apparent at the very fine scale of the size of small headwater catchment (Sroczynska et al., 2017).

Patterns in macroinvertebrate communities and habitat specific associations are well described for temperate, perennial rivers (Kubosova et al., 2010, Schröder et al., 2013). However, little attention on this topic has been paid to intermittent Mediterranean streams (however see García-Roger et al., 2013 and Leitão et al., 2014). While few studies demonstrated some 
tendencies in macroinvertebrate preferences to inhabit certain habitats (Chakona et al., 2008; García-Roger et al., 2013), others found no consistent patterns (Winterbourn et al., 1981). On the other hand, some authors have demonstrated that preferences of macroinvertebrates for specific types of habitat are less pronounced and dominated by generalist traits in streams with higher frequency and magnitude of disturbance, such as temporary streams (Death \& Winterbourn, 1995, Sánchez-Carmona et al., 2012, Datry et al., 2013). Therefore, it is unclear if previous knowledge about patterns in community structure and taxa-specific associations, established for perennial streams, are of the same relevance in temporary streams. Stream typology was shown to be also an important determinant of macroinvertebrate distribution patterns (Sánchez-Montoya et al., 2007) in these types of streams. Based on macroinvertebrate distribution in Europe, differences between Mediterranean stream types were much smaller than in other areas (Verdonschot \& Nijboer, 2004). The reason for that can be associated to extreme hydrological conditions prevailing at most of Mediterranean streams. High variability in macroinvertebrate communities and biotic metrics has been observed in dry and wet periods even in reference streams (Sánchez-Montoya et al., 2009b, Munné \& Prat, 2011) with a strong influence of flow connectivity (Datry et al., 2011, Datry et al., 2013, Prat et al., 2013, Cid et al., 2016). These extreme environmental conditions can override stream type differences. As such, a proper understanding of the effect of typology and habitat on macroinvertebrate occurrences in these types of streams is still lacking.

This knowledge is of great importance, as the scale (habitat/stream) at which the variation in macroinvertebrate communities is the highest will likely cause discrepancies in water quality index and consequently will limit its comparability with other water bodies. Therefore, an identification of the scale at which such variability occurs will greatly improve protocols for water quality assessment.

Habitat unit (considered as an area of the stream visually distinct from its surrounding) is often used to evaluate heterogeneity and success of the restoration efforts (Armitage \& Pardo, 1995, Lepori et al., 2005). When applying rapid bio assessment protocols, some authors suggested stratified sampling through the habitat types encountered at the sampling sites to decrease the variation among samples and improve comparisons among sites (Armitage \& Pardo, 1995, Resh \& Jackson, 1993). On other hand, according to hierarchical scale dynamics, environmental filter acting at regional scale is stronger in determining macroinvertebrate assemblages than habitat filter (Poff, 1997).

Drawing from hierarchical scale dynamics theory and based on studies from perennial streams and on few existing studies of intermittent streams (García-Roger et al., 2013, Leitão et al., 2014) we expect that at higher hierarchical scale (typology) patterns in macroinvertebrates distribution will be more apparent than at a finer habitat scale resulting in differences in community metrics and water quality indices (H1). We also expect to find high number of taxa significantly associated to certain typologies. In turn we expect to find more generalistic patterns in macroinvertebrate distribution among habitats resulting in less variable community metrics and water quality indices and also in low habitat-specific number of taxa (H2). Further, we assumed that habitat will interact with typology of the stream. Therefore, our last hypothesis (H3) predicts that community metrics and water quality index will depend on the interaction between habitats and stream types.

To test these hypotheses, we investigated macroinvertebrate assemblage structure at distinct habitat types within different types of streams. Additionally, to community characteristics we tested the strength of associations of macroinvertebrates to habitat structure as well typology using indicator values (Dufrene \& Legendre 1997). Further we measured the interaction effect of habitat and stream type on community characteristics (number of families, abundance, taxa richness) and biotic index (IPtIs -Índice Português de Invertebrados Sul- INAG, 2009). Iptis is a multimetric index specifically developed for Portuguese streams and rivers as part of the European inter-calibration freshwater group exercise (INAG, 2009). 


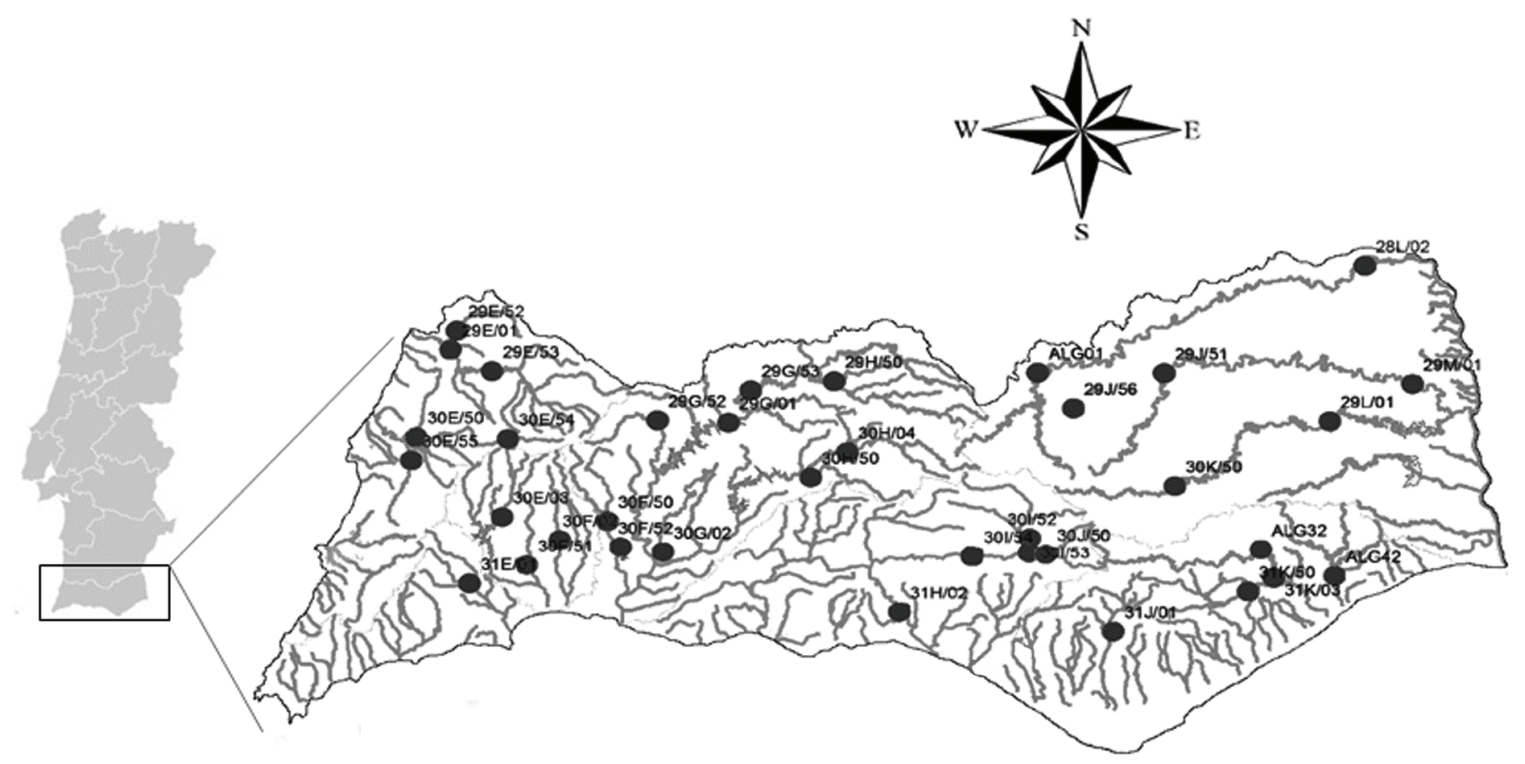

Figure 1. Map indicating the Algarve region of southern Portugal with the 36 sampling sites, which are part of the monitoring grid defined by the Water Institute I. P. (INAG). Mapa que indica a região Algarvia no sul de Portugal com os 36 locais de amostragem, que fazem parte da rede de monitorização definida pelo Instituto da Água I. P. (INAG).

\section{METHODS}

\section{Study area}

The study area covered the Hydrographical Administrative Region for the Algarve (ARH-Algarve), located in southern Portugal (Fig. 1). The region is characterized by Mediterranean-type climate, where habitat structuration processes are shaped by sequential events of annual flooding and drying (Trigo et al., 2004), which directly affects substrate characteristics, the development of algae and macrophytes as well as accumulation of organic debris (Gasith \& Resh, 1999, Sabater et al., 2006).

Wet periods begin in late October and generally last until April, with maximum discharge peaks occurring during winter months (November-March). During the dry season ( June September) the stream fragments dry into temporarily disconnected pools or completely dry channels. Sampling was conducted by APA-ARH following the mandatory WFD inter calibration panel guidelines. Sampling period took place in early-middle Spring (April), during the period of moderate flow and considering a lag time of 15 days after the last intensive rain occurrence (necessary time for macroinvertebrate re-colonization defined by EU inter-calibration panel).

The sampling points were selected from the monitoring grid defined by the Portuguese Water Institute I.P. (INAG) for the Algarve Water District (ARH Algarve), which included 46 obligatory sampling sites. Those sampling sites were validated in the field considering the influence of source pollution and seawater intrusion and, taking into account these criteria, a total of 40 sites were sampled. From those 40 sampling points only 36, that presented Good Ecological Status, were selected for the purpose of this study. Selection was based on Chícharo et al. (2009) that evaluated water quality at given sites taking into consideration biological elements (macroinvertebrates, diatomaceous, fish and vegetation), physical-chemical elements as well river habitat survey following the mandatory WFD guidelines. These 36 sites were classified according to four main typologies (INAG, 2008): southern rivers from medium to large dimensions 
(M-L) - 6 sites; southern mountainous rivers (M-S) - 5 sites; southern small rivers (S-S) - 13 sites; calcareous rivers of Algarve (C) -12 sites (See Table S1. Supplementary information, available at http://www.limnetica.net/en/limnetica). All of the sampled sites except for four are intermittent. In remaining four sites the water flows all over the year, due to the existence of groundwater discharge.

\section{Sampling methods}

Sampling of benthic macroinvertebrates was conducted in 2009 following the WFD compliant INAG benthic macroinvertebrate sampling protocol. In accordance with mentioned protocol, sampling was conducted during the month of April when stable hydraulic conditions prevail, in order to ensure that all the temporary habitats were present at the moment of sampling. Within each site, a representative $50 \mathrm{~m}$ section was defined considering the riffle zone and the adjacent sedimentation zones, in a way to best represent the diversity of the habitats present (Table S1, Supplementary information). Sampled habitats included 4 inorganic substrate types (according to their granulometry Schroder et al., 2013): boulder $(>25.6 \mathrm{~cm})$, cobble $(6.4-25.6$ $\mathrm{cm})$, gravel $(0.2-6.4 \mathrm{~cm})$ and sand $(<0.2 \mathrm{~cm})$; and 2 organic substrate types: macrophytes (algae and aquatic plants) and POM (particulate organic matter) as defined by INAG (2009).

Benthic macroinvertebrate samples were collected using a hand-net (of $0.5 \mathrm{~mm}$ mesh and $25 \mathrm{~cm}$ width) and a standardized kick sampling method (each "sampling unit" was $1 \mathrm{~m}$ long and $0.25 \mathrm{~m}$ wide) in all habitats that were present in a section, independently on their percentage cover. Sample contents were placed in plastic containers and preserved using $96 \%$ ethanol.

\section{Sample processing and macroinvertebrate taxa identification}

Macroinvertebrates were sorted and examined using a stereomicroscope and identified to family level, with the exception of two taxa that were identified to a higher level: subclass Oligochaeta and order Araneae. Family level identification is the required to estimate the biotic index used to assess water quality, according to the objectives of the WFD. No sub-sampling was used regardless of the number of individuals.

\section{Data Analyses}

PERMANOVA (permutational multivariate analysis of variance) was used to test for significant differences in macroinvertebrate community composition and structure, using a Bray-Curtis similarity matrix of presence/absence data, with stream Typology and Habitat as orthogonal fixed factors. Ordination by non-metric multidimensional scaling (nMDS) was used to visualise patterns. nMDS allows converting similarity in distance, which is represented spatially, using the Unweighted Pair Group Method (UPGMA). In order to facilitate visualization, the MDS plots were built on a reduced presence/absence matrix, by averaging the replicates in each combination of Habitat (6 types) and Typology (4 types) subtracted by three types of habitats that were not present at the typology M-S, resulting in total of 21 points visible on the MDS plot. The similarity percentages routine (SIMPER) was used to examine the contribution of each macroinvertebrate family to average resemblances between sample groups. All multivariate analyses were done using the PRIMER 6 statistical package with the PERMANOVA+ add-on (PRIMER-e, Plymouth Marine Laboratory).

For each taxa the IndVal - indicator value of association (Dufrene \& Legendre, 1997) was calculated, using function "strassoc" and "IndVal.g" as the association index. Associations to group combinations of stream habitats and typologies were tested in order to evaluate if some taxa can display a more generalist distribution and be associated with more than one group. Indicator value for group combinations was done using function "multipatt". All the IndVal analysis were done using "indicspecies" package in R software (De Caceres \& Legendre, 2009). Taxa with a significant association to one group or group combinations were crossed with the list of families, which contributed the most to the dissimilarities among stream habitats or typologies, calculated using SIMPER 
analyses (Clarke \& Warwick, 2001). Vectors representing the correlations between the frequency of occurrence of these selected taxa and the dissimilarity matrix were superimposed on the nMDS ordination.

Diversity (total number of families, total number of individuals and Simpson diversity) and water quality indices (IPtIs) were calculated for each macroinvertebrate sample. The IPtIS index used for this analysis was calculated based on presence/absence of particular macroinvertebrate families, their species richness, abundance and sensibility to pollution:

IPtIs $=\left(N^{o}\right.$ offamilies $\left.\times 0.4\right)+(E P T \times 0.2)+$ $((I A S P T-2) \times 0.2)+(\log ($ Sel. EPTCD +1$)$ $\times 0.2)$

Where:

EPT $=$ number of families, which belong to the orders Ephemeroptera, Plecoptera and Trichoptera.

IASPT (Iberian Average Score per Taxa) = this index corresponds to IBMWP index (Iberian Biological Monitoring Working Party index, Alba-Tercedor et al., 2002) divided by the number of families

$\log ($ Sel. EPTCD $)=\log 10$ of $1+$ sum of individuals, which belongs to individuals of the following families: Chloroperlidae, Nemouridae, Leptophlebiidae, Ephemerellidae, Philipotamidae, Elmidae, Leuctridae, Limnephilidae, Sericostomatidae, Dryopidae, Athericidae.

Two-way analysis of variance (ANOVA) was performed on community metrics (total number of families, total number of individuals and Simpson diversity) and water quality index (IPtIs) with Typology and Habitat as fixed orthogonal factors. Pairwise Multiple Comparisons among habitats and typologies were done using Student-Newman-Keuls procedure. All the univariate analyses were done using SigmaPlot software (Version 11.0, Systat Software, Inc.).

\section{RESULTS}

\section{Community structure}

9448 individuals were sampled in total from all of the habitats, with minimum density of 7 individuals $/ \mathrm{m}^{2}$ (on the habitat sand and POM belonging to $\mathrm{C}$ and M-L typologies respectively) and maximum 529 individuals $/ \mathrm{m}^{2}$ (on habitat macrophytes at the $\mathrm{C}$ type), with a total of 75 families identified. The highest mean abundance and number of families was on M-S streams. The lowest mean abundance was on M-L streams and the lowest number of families was found on $\mathrm{C}$ streams (Fig. 2A and $\mathrm{B}$ ).

For the habitat, the highest mean abundance as well as number of families was found on habitat cobble, while the lowest were on habitats sand and POM (Fig. 2A and B).

PERMANOVA analysis for abundance data and for presence/absence data was not significant for the interaction between Typology and Habitats. Nonetheless, significant main effects of Typology and Habitat were detected, indicating that these two factors independently influence community assemblage structure (Table 1). Average similarity values between/within groups are summarized in Table 2. Given that the response was similar in terms of abundance and presence/absence data, only the latter is presented. Stream typologies differed significantly among the S-S typology and the remaining three typologies, as well as among M-S and M-L and M-L and C. The most similar typologies were $\mathrm{M}-\mathrm{S}$ and $\mathrm{C}$. For habitats, main differences were observed among depositional habitats (sand and POM) and coarse mineral habitats (boulder, cobble, gravel), but differences were also recorded among macrophytes and gravel and macrophytes and cobble. The most similar habitats were boulder, cobble and gravel.

nMDS analyses showed high similarity among boulder, cobble, gravel and macrophytes habitats (Fig. 3A). POM and sand were detached from the rest of the habitats and showed the smallest levels of similarity within the same habitat (Table 2). Ancylidae and Heptageniidae were strongly associated with the inorganic habitats: cobble, gravel and boulder. This is also corroborated by the IndVal values where Ancylidae had 
A

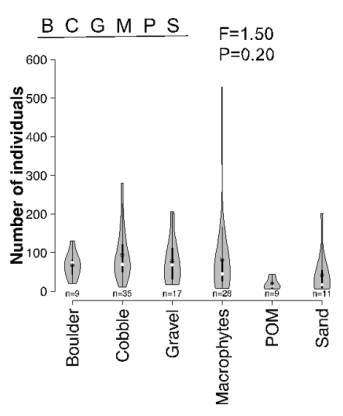

Habitats

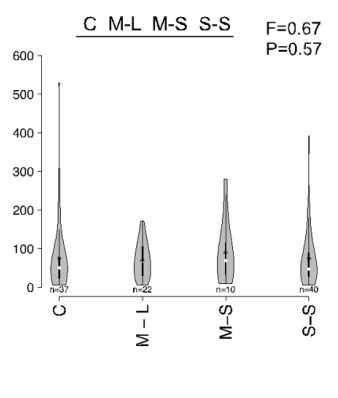

Typologies

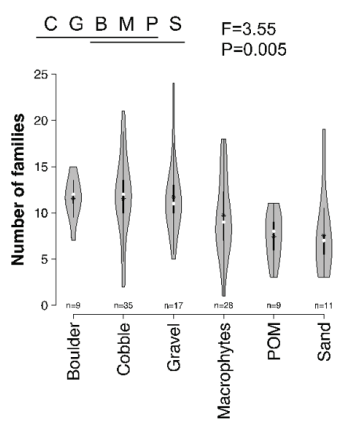

Habitats

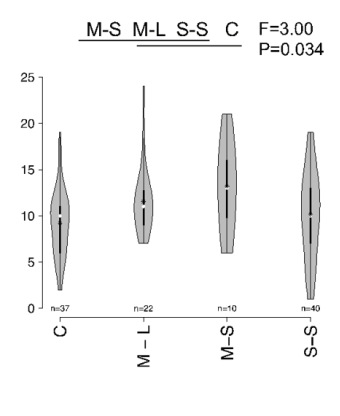

Typologies

D
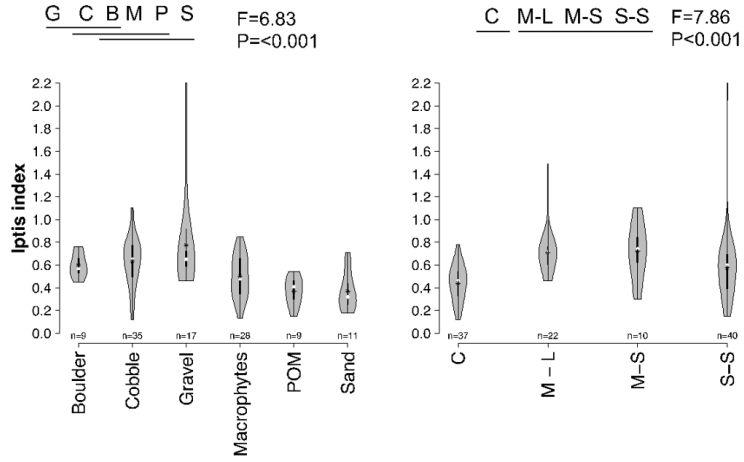

Habitats

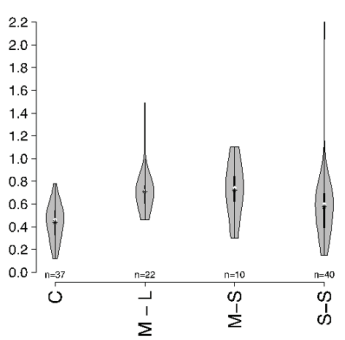

Typologies

Habitats

Typologies

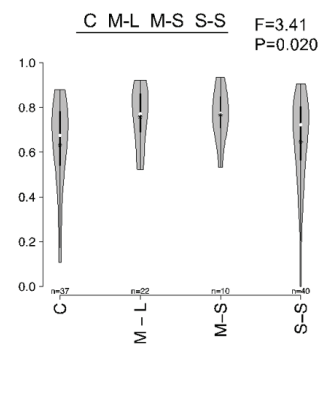

Figure 2. Violin plots with number of individuals (A); number of families (B) per $\mathrm{m}^{-2}$; Simpson diversity index (C) and IPtIs index (D) for Habitat and Typology. Grey-shaded area represents the sample distribution where: asterisk represents a mean, white circle is a median with the thick vertical lines at the first and third quartiles and thin vertical lines that extends to maximum and minimum value. F - statistics of the Two-way analysis of variance, considering two fixed, orthogonal factors: Typology and Habitat. For Habitat/Typologies that are underlined with the same line no difference at $p \leq 0.05$ was recorded in multiple comparison (Student-Newman-Keuls) tests. "Violin plots" com número de famílias (A); número de indivíduos (B) por $\mathrm{m}^{-2}$; índice de diversidade de Simpson (C) e índice do IPtIs para cada habitat e para cada tipologia do rio. A área sombreada representa a distribuição da amostra onde: o asterisco representa a media, o círculo branco é uma mediana com as linhas verticais grossas no primeiro e terceiro quartis e finas linhas verticais que se estendem ao valor máximo e mínimo $F$ - estatístico das analises de variância de duas vias de fatores ortogonais fixos (habitat e tipologia). De acordo com o teste de comparações múltiplas de Student-Newman-Keuls (p $\leq 0.05)$ para os fatores Habitat e tipologia que estão sublinhados com a mesma linha não existem diferenças significativas.

significant association to boulder (Table 3 and 4), whereas, Heptageniidae had strong association to the combination of three course mineral substrates (boulder, cobble and gravel, Table 4). Whereas Elmidae and Perlodidae displayed some affinities to macrophytes (Fig. 3A), with respective high IndVal for this habitat and for the group combinations among coarse mineral and macro- phytes substrate (Table 3 and 4). Physidae were associated both with POM and less strongly with Sand. According to nMDS Dolichopodidae and Ephemerelidae were clearly associated with sand (Fig. 3A). Nonetheless, Table 3 and Table 4 also demonstrates high association of these taxa for the cobble and gravel and for Ephemerelidae also for boulder and macrophytes. 
Table 1. PERMANOVA analysis with two fixed factors (Typology and Habitat) based on presence/absence similarity matrix. Análise PERMANOVA com dois fatores fixos (Tipologia e Habitat) com base na matriz de similaridade de presença/ausência.

\begin{tabular}{ccccccc}
\hline Source & df & SS & MS & Pseudo-F & $P$ & Perms \\
\hline Typology & 3 & 12565 & 4188 & 2.517 & 0.001 & 997 \\
Habitat & 5 & 17947 & 3589 & 2.157 & 0.001 & 998 \\
Typ $\times$ Hab. & 12 & 18150 & 1512 & 0.909 & 0.725 & 997 \\
Res & 90 & 149740 & 1663 & & & \\
Total & 110 & 2051 & & & & \\
\hline
\end{tabular}
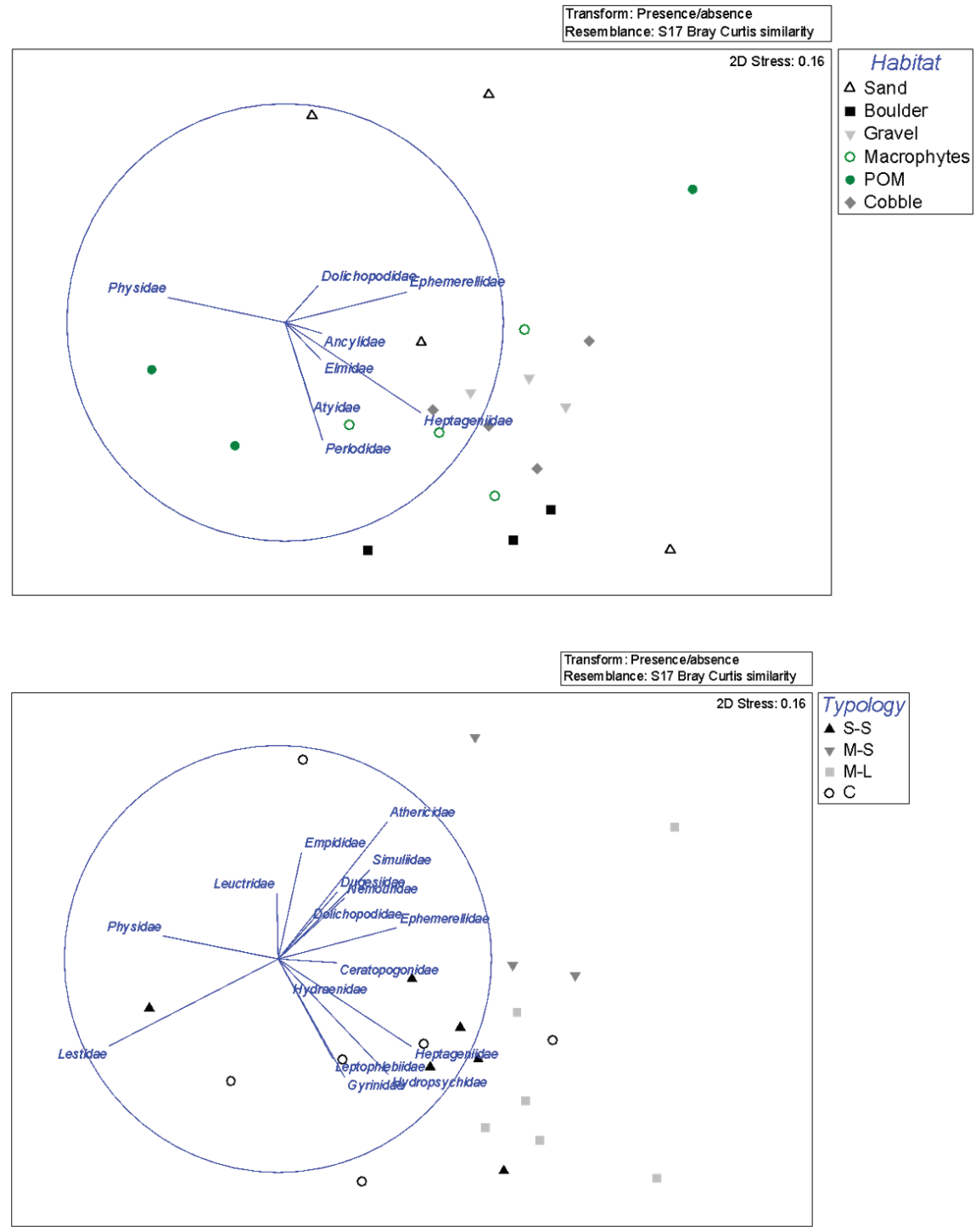

Figure 3. Non-metric multi-dimensional scaling (nMDS) for Habitat and Typology; vectors represent the correlations between the nMDS ordination and correlations between the frequency of ocurrence of taxa selected for each factor and the presence/absence similarity matrix. Non-metric multi-dimensional scaling (nMDS) para Habitat e Tipologia; Os vectores representam as correlações entre a coordenação do nMDS e as correlações entre a frequência de ocorrência de taxa selecionados para cada factor e matriz de similaridade de presencia/ausencia. 
Different sets of taxa were related with different Typologies (Fig. 3B). Common rheophilic taxa such as Heptagenidae, Leptophlebiidae, Hydropsychidae and Gyrinidae were associated with M-L typology. Although Leptophlebiidae was also strongly associated with S-S typology (Tables 3 and 4). Few common families such as Simuliidae, Nemouridae, Athericidae, Dugesiidae and Dolichopodidae were evidently affiliated to M-S Typology. M-S typology is also the one with the highest number (8) of families with significant IndVal (Table 4).

Only Heptageniidae, Physidae and Dolichopodidae had common patterns in their associations to both Habitat and Typology. Heptagenidae family was associated to coarse mineral substrates and M-L typology. Physidae was associated to both C and S-S typologies and previously mentioned POM and Sand habitats. Dolichopodidae was closely related to gravel/sand and M-S typology. Remaining families rather displayed affiliations to either Habitat or Typology.

Families with the highest contribution to dissimilarity among habitats and typologies

Table 2. Table with average similarity between/within groups for habitats (A) and Typologies (B) according to SIMPER analysis. In bold are depicted habitat/typologies pairs with significant differences according to PERMANOVA pair-wise tests. Similaridade média entre/dentro de grupos para habitats (A) e Tipologias (B). A preto estão representados os pares de habitat/tipologia com diferenças significativas de acordo com os testes pair-wise da PERMANOVA.

A

\begin{tabular}{ccccccc}
\hline & Sand & Boulder & Gravel Macrophyte & POM Cobble \\
\hline Sand & 37.33 & & & & & \\
Boulder & $\mathbf{3 4 . 6 7}$ & 47.99 & & & & \\
Gravel & 40.17 & $\mathbf{4 3 . 9 8}$ & 49.25 & & & \\
Macrophyte & $\mathbf{3 6 . 3 2}$ & 42.93 & $\mathbf{4 3 . 2 0}$ & 41.10 & & \\
POM & 31.48 & $\mathbf{3 1 . 1 1}$ & $\mathbf{3 1 . 7 2}$ & 34.27 & 31.83 & \\
Cobble & $\mathbf{3 7 . 0 9}$ & 44.68 & 46.90 & $\mathbf{4 1 . 5 2}$ & $\mathbf{3 0 . 8 6}$ & 44.60 \\
\hline
\end{tabular}

B

\begin{tabular}{ccccc}
\hline & S-S & M-S & M-L & C \\
\hline S-S & 41.62 & & & \\
M-S & $\mathbf{3 8 . 2 9}$ & 41.59 & & \\
M-L & $\mathbf{4 5 . 9 5}$ & $\mathbf{4 3 . 5 8}$ & 55.04 & \\
C & $\mathbf{3 7 . 6 2}$ & 35.61 & $\mathbf{4 0 . 9 5}$ & 37.50 \\
\hline
\end{tabular}

greatly coincide with families with significant IndVal (Table 3 and 4). Only Leptophlebiidae for habitat and Philipotamidae and Calopterygidae families for Typology have significant IndVal, but does not contribute to overall dissimilarity. Typology had 15 taxa with significant IndVal, from which 11 taxa were associated to one type of stream, whereas 6 families were associated to the stream types combinations. Habitat had seven families, which IndVal was significantly different among habitats (Table 3). However, from these seven families only one taxon had significant IndVal for only one habitat type and remaining taxa had only significant associations to habitat combinations (Table 4).

\section{Diversity and water quality indices}

As previously demonstrated by the multivariate analysis Habitat vs Typology interaction was not significant for community data (neither for abundance data, nor for the presence/absence data) and for this reason we decide not to include the interaction analysis for the community descriptors. However, 2-way analysis of variance detected significant main effect of Typology and Habitat on IPtIs water quality index and number of families (Fig. 2B and D). Simpson diversity index was only significant for Typology (Fig. 2C). In terms of water quality index, the differences were between $\mathrm{C}$ typology, which had the lowest IPtIs value (Fig. 2D), and the remaining typologies. For the habitat types the differences were found among Gravel, with the highest IPtIs value, and Sand, POM and Macrophytes, with the respective lowest IPtIS values. Number of families differed only between M-S typology, which hosted the highest mean number of families (Fig. 2B), and C typology, with the lowest. For the habitats, multiple comparisons test detected only significant differences among Sand (with the lowest number of families) and gravel and cobble, with the respective highest number of families for all of the habitats.

\section{DISCUSSION}

Our first hypothesis (H1) assumed that Typology will influence macroinvertebrate assemblages 
Table 3. Values of IndVal for chosen taxa in each habitat and typology; values in bold represent taxa whose indVal significantly differ among groups; the highest IndVal for each habitat/typology is represented on grey. Valores de IndVal para taxa escolhidos em cada habitat e tipologia. Os valores a preto representam taxa cujo indVal diferiu significativamente entre os grupos. O IndVal mais alto para cada habitat/tipologia está representado a cinza.

\begin{tabular}{cccccccc}
\hline HABITAT & Boulder & Cobble & Gravel & Macrophytes & POM & Sand & $P$ \\
\hline Ancylidae & $\mathbf{0 . 5 4}$ & $\mathbf{0 . 2 6}$ & $\mathbf{0 . 2 1}$ & $\mathbf{0 . 0 7}$ & $\mathbf{0 . 0 0}$ & $\mathbf{0 . 0 8}$ & $\mathbf{0 . 0 4}$ \\
Atyidae & $\mathbf{0 . 1 3}$ & $\mathbf{0 . 1 3}$ & $\mathbf{0 . 0 9}$ & $\mathbf{0 . 5 6}$ & $\mathbf{0 . 2 4}$ & $\mathbf{0 . 0 0}$ & $\mathbf{0 . 0 4}$ \\
Dolichopodidae & $\mathbf{0 . 0 0}$ & $\mathbf{0 . 3 2}$ & $\mathbf{0 . 4 2}$ & $\mathbf{0 . 0 3}$ & $\mathbf{0 . 0 9}$ & $\mathbf{0 . 2 6}$ & $\mathbf{0 . 0 2}$ \\
Elmidae & $\mathbf{0 . 3 7}$ & $\mathbf{0 . 5 9}$ & $\mathbf{0 . 3 5}$ & $\mathbf{0 . 3 2}$ & $\mathbf{0 . 0 8}$ & $\mathbf{0 . 0 9}$ & $\mathbf{0 . 0 5}$ \\
Ephemereliidae & 0.22 & 0.40 & 0.29 & 0.36 & 0.05 & 0.07 & 0.14 \\
Heptageniidae & $\mathbf{0 . 4 0}$ & $\mathbf{0 . 4 3}$ & $\mathbf{0 . 3 8}$ & $\mathbf{0 . 0 7}$ & $\mathbf{0 . 0 0}$ & $\mathbf{0 . 0 4}$ & $\mathbf{0 . 0 1}$ \\
Perlodidae & $\mathbf{0 . 3 9}$ & $\mathbf{0 . 5 6}$ & $\mathbf{0 . 2 3}$ & $\mathbf{0 . 2 0}$ & $\mathbf{0 . 1 2}$ & $\mathbf{0 . 0 2}$ & $\mathbf{0 . 0 3}$ \\
Physidae & $\mathbf{0 . 0 6}$ & $\mathbf{0 . 0 4}$ & $\mathbf{0 . 0 0}$ & $\mathbf{0 . 1 8}$ & $\mathbf{0 . 5 0}$ & $\mathbf{0 . 2 2}$ & $\mathbf{0 . 0 5}$ \\
\hline TYPOLOGY & $\mathrm{C}$ & M-L & M-S & S-S & & & $P$ \\
\hline Athericidae & $\mathbf{0 . 1 1}$ & $\mathbf{0 . 2 1}$ & $\mathbf{0 . 5 3}$ & $\mathbf{0 . 1 4}$ & & $\mathbf{0 . 0 3 0}$ \\
Ceratopogonidae & $\mathbf{0 . 1 7}$ & $\mathbf{0 . 4 4}$ & $\mathbf{0 . 2 0}$ & $\mathbf{0 . 4 9}$ & & $\mathbf{0 . 0 2 0}$ \\
Dolichopodidae & $\mathbf{0 . 0 5}$ & $\mathbf{0 . 3 9}$ & $\mathbf{0 . 4 5}$ & $\mathbf{0 . 2 1}$ & & $\mathbf{0 . 0 0 5}$ \\
Dugesiidae & $\mathbf{0 . 0 0}$ & $\mathbf{0 . 1 4}$ & $\mathbf{0 . 3 9}$ & $\mathbf{0 . 0 2}$ & & $\mathbf{0 . 0 2 5}$ \\
Empididae & $\mathbf{0 . 0 0}$ & $\mathbf{0 . 0 9}$ & $\mathbf{0 . 3 9}$ & $\mathbf{0 . 0 3}$ & & $\mathbf{0 . 0 4 5}$ \\
Ephemerellidae & $\mathbf{0 . 0 9}$ & $\mathbf{0 . 2 7}$ & $\mathbf{0 . 2 8}$ & $\mathbf{0 . 6 1}$ & & $\mathbf{0 . 0 0 5}$ \\
Gyrinidae & $\mathbf{0 . 0 0}$ & $\mathbf{0 . 3 6}$ & $\mathbf{0 . 0 0}$ & $\mathbf{0 . 0 4}$ & & $\mathbf{0 . 0 3 5}$ \\
Heptageniidae & $\mathbf{0 . 0 4}$ & $\mathbf{0 . 6 8}$ & $\mathbf{0 . 1 8}$ & $\mathbf{0 . 2 8}$ & & & $\mathbf{0 . 0 0 5}$ \\
Hydraenidae & $\mathbf{0 . 0 5}$ & $\mathbf{0 . 0 7}$ & $\mathbf{0 . 5 1}$ & $\mathbf{0 . 0 8}$ & & $\mathbf{0 . 0 1 0}$ \\
Hydropsychidae & 0.23 & 0.43 & 0.45 & 0.22 & & 0.065 \\
Leptophlebiidae & $\mathbf{0 . 1 4}$ & $\mathbf{0 . 5 9}$ & $\mathbf{0 . 1 9}$ & $\mathbf{0 . 5 0}$ & & & $\mathbf{0 . 0 0 5}$ \\
Lestidae & $\mathbf{0 . 4 5}$ & $\mathbf{0 . 0 2}$ & $\mathbf{0 . 0 0}$ & $\mathbf{0 . 0 8}$ & & $\mathbf{0 . 0 2 0}$ \\
Leuctridae & $\mathbf{0 . 0 9}$ & $\mathbf{0 . 2 2}$ & $\mathbf{0 . 5 4}$ & $\mathbf{0 . 1 3}$ & & $\mathbf{0 . 0 1 0}$ \\
Nemouridae & $\mathbf{0 . 0 0}$ & $\mathbf{0 . 0 5}$ & $\mathbf{0 . 5 9}$ & $\mathbf{0 . 0 4}$ & & $\mathbf{0 . 0 0 5}$ \\
Physidae & $\mathbf{0 . 4 8}$ & $\mathbf{0 . 0 4}$ & $\mathbf{0 . 1 6}$ & $\mathbf{0 . 0 7}$ & & $\mathbf{0 . 0 2 0}$ \\
Simuliidae & $\mathbf{0 . 3 0}$ & $\mathbf{0 . 0 9}$ & $\mathbf{0 . 6 8}$ & $\mathbf{0 . 1 2}$ & & $\mathbf{0 . 0 2 0}$ \\
\hline & & & & & &
\end{tabular}

and so it was supported. Observed differences in macroinvertebrate communities among almost all of the stream typologies validate the general belief that the intermittent river systems are extremely heterogeneous group in comparison to other stream types (Sánchez-Montoya et al., 2007). Differences among stream typologies are particularly worth attention taking into consideration the gross taxonomic resolution used in the present study. In general, the finer taxonomic resolution, the clearer separation of stream classes (Lorenz et al., 2004). The fact that the differences in typologies were evident at such gross resolution provides an additional argument that refinement of such intermittent system is necessary to adequately capture taxa patterns and better reflect water quality measures. In addition, high number of significantly associated taxa indicates that at this scale taxa specific preferences are displayed on the stream level and less at the habitat level. However, in terms of number of individuals and Simpson diversity index there were no differences among different Typologies and IPtIS index only differed for calcareous streams. The results demonstrate that although remaining typologies support different communities, this fact is not automatically reflected in the differences in IPtIs index among these stream types.

Our second hypothesis (H2) assumed that the structure of macroinvertebrate community at the habitat level will follow more generalistic patterns with smaller differences among habitats 
Table 4. Groups combination for habitat types and stream typologies, with A and B values and stat = test statistic 'IndVal.g'; only taxa with significant IndVal are listed. Combinação de grupos para tipos de habitat e tipologias, com valores A e B e stat $=$ teste estatístico 'IndVal.g'. Apenas os taxa com IndVal significativo estão listados.

\begin{tabular}{|c|c|c|c|c|c|}
\hline Groups and groups combinations & Taxa & A & $\mathrm{B}$ & stat & $P$ \\
\hline Boulder & Ancylidae & 0.45 & 0.67 & 0.55 & 0.04 \\
\hline Boulder + Cobble + Gravel & Heptageniidae & 0.97 & 0.50 & 0.70 & 0.00 \\
\hline Boulder + Macrophytes + POM & Atyidae & 0.87 & 0.43 & 0.61 & 0.03 \\
\hline Cobble + Gravel + Sand & Dolichopodidae & 0.92 & 0.41 & 0.61 & 0.02 \\
\hline Macrophytes + POM + Sand & Physidae & 0.95 & 0.27 & 0.50 & 0.04 \\
\hline Boulder + Cobble + Gravel + Macrophytes & Elmidae & 0.92 & 0.78 & 0.85 & 0.03 \\
\hline \multirow[t]{2}{*}{ Boulder + Cobble + Gravel + Macrophytes + POM } & Leptophlebiidae & 0.99 & 0.57 & 0.75 & 0.03 \\
\hline & $\begin{array}{l}\text { Perlodidae } \\
\text { TYPOLOGIES }\end{array}$ & 0.99 & 0.50 & 0.71 & 0.04 \\
\hline $\mathrm{C}$ & Lestidae & 0.93 & 0.22 & 0.45 & 0.03 \\
\hline \multirow[t]{2}{*}{ M-L } & Heptageniidae & 0.67 & 0.68 & 0.68 & 0.01 \\
\hline & Gyrinidae & 0.93 & 0.14 & 0.36 & 0.03 \\
\hline \multirow[t]{8}{*}{ M-S } & Simuliidae & 0.57 & 0.80 & 0.68 & 0.01 \\
\hline & Nemouridae & 0.86 & 0.40 & 0.59 & 0.01 \\
\hline & Leuctridae & 0.58 & 0.50 & 0.54 & 0.01 \\
\hline & Athericidae & 0.55 & 0.50 & 0.53 & 0.01 \\
\hline & Hydraenidae & 0.87 & 0.30 & 0.51 & 0.03 \\
\hline & Dugesiidae & 0.77 & 0.20 & 0.39 & 0.04 \\
\hline & Empididae & 0.76 & 0.20 & 0.39 & 0.04 \\
\hline & Calopterygidae & 0.67 & 0.20 & 0.37 & 0.05 \\
\hline $\mathrm{C}+\mathrm{M}-\mathrm{S}$ & Physidae & 0.90 & 0.28 & 0.51 & 0.04 \\
\hline \multirow[t]{2}{*}{$\mathrm{M}-\mathrm{L}+\mathrm{M}-\mathrm{S}$} & Dolichopodidae & 0.83 & 0.44 & 0.60 & 0.01 \\
\hline & Philopotamidae & 0.97 & 0.16 & 0.39 & 0.04 \\
\hline \multirow[t]{3}{*}{$\mathrm{M}-\mathrm{L}+\mathrm{M}-\mathrm{S}+\mathrm{S}-\mathrm{S}$} & Leptophlebiidae & 0.94 & 0.65 & 0.78 & 0.01 \\
\hline & Ephemerellidae & 0.96 & 0.53 & 0.72 & 0.01 \\
\hline & Ceratopogonidae & 0.90 & 0.55 & 0.70 & 0.03 \\
\hline
\end{tabular}

than at the Typology scale. This hypothesis was partially supported. Macroinvertebrates communities differed among certain habitat types, particularly between marginal habitats: sand and POM and the rest of the habitats. This finding supports the concept that macroinvertebrates follow the erosional-depositional gradient in their distribution patterns among habitats (Sheldon \& Haick, 1981, Barmuta, 1989, Chakona et al., 2008 García-Roger et al., 2011).

Other authors have demonstrated that the degree of bed movement (critical force needed to move median particle diameter) and availability of interstitial space are critical factors for the distribution of invertebrates (Cobb et al., 1992, Townsend et al., 1997, Duan et al., 2008). Therefore, boulder, cobble and gravel supported higher number of families presumably by providing greater stability in terms of resistance to disturbance during flood events as well as by serving as refuge (Rice et al., 2001). It is then expected to find greater similarities in macroinvertebrate communities among these three mineral substrates that among organic ones. Such pattern is likely related to the fact that these habitats are located at more erosional section of the channel, supporting fauna adapted to higher current velocities. An overlap among macroinvertebrate families, particularly within mineral substrata, was also observed for temperate rivers (Rabeni \& Gibbs, 1980, Barmuta, 1989) and in general is associated with high mobility of most invertebrate taxa within a reach (Mackay, 1992). Furthermore, nMDS analysis showed that macrophytes tended to be more similar in terms of taxonomic composition to the latter three habitats. One of the possible explanation for such pattern is that macrophytes provide internal microclimate for stream biota and therefore majority of mobile taxa will more likely broaden 
their distribution from central-channel mineral substrata to the macrophyte areas, where the probability of finding food resources, as well as shelter for spawning and nursery space, will be higher (Pardo \& Armitage, 1997). An adaptive generalist response of benthic fauna to relocate among habitats potentially explains why some taxa had only significant associations to group combinations between mineral substrates and macrophytes rather than solely mineral or organic. Alternatively, predator avoidance or competition could also explain this pattern (Menge \& Olson, 1990). Only one taxa had significant IndVal in relation to certain type of habitat (Ancylidae), while most of the remaining taxa displayed more generalistic distribution among coarse organic substrates and macrophytes, what confirms our initial hypothesis. Similar pattern was observed for temperate permanent streams (Armitage \& Cannan, 2000), but also for intermittent (Datry et al., 2013).

Low number of taxa with significant indicator values impels us to identify habitats with the highest ecological importance for macroinvertebrate distribution. Previous studies conducted on temporary rivers demonstrated that cobble and macrophytes habitats constituted distinct communities and were strongly preferable by macroinvertebrates in comparison to gravel and sand (Chakona et al., 2008). We demonstrated that indeed cobble and macrophytes were important habitats for some families, but they do not support distinct communities. Intermittent streams, with the prevalence of floods and droughts might have favoured the evolution of generalist traits (Hershkovitz \& Gasith, 2013, Datry et al., 2013) in order to enhance the resilience of biota to withstand conditions of frequent disturbance (Williams, 1996). Such tactic employs lesser selectivity in terms of resource partitioning (Mihuc, 1997, Vannucchi et al., 2013, Rosi-Marshall et al., 2016,) what in consequence hampers defining ecological niches for majority of taxa at intermittent streams. In the same way as it had place at the Typology level, number of individuals and Simpson diversity index did not differ among habitats. Nevertheless, IPtIs index differed among habitats, being the highest for gravel, following by cobble and boulder-three habitats, which mainly differed from the rest of the habitats in terms of community assemblages. Nonetheless, only gravel significantly differed from other habitats in terms of IPtIs.

Our initial hypothesis predicted that typology will be responsible for higher variations in macroinvertebrate communities than habitat. In turn, both factors are important determinants for macroinvertebrate distributions and it clearly emphasizes how patterns in macroinvertebrate occurrences are scale dependent. It is also in agreement with very low (3 out of 24 taxa) number of taxa, which exhibited common patterns in their distribution to both Typology and Habitat. Remaining taxa displayed only association to one of these factors.

It is also possible that habitat, to be a predictable unit of species assemblages, needs to be considered at smaller scale such as one stream type or reach, where the environmental parameters are homogenous. Low concordance between taxa assemblages and substrates were also found at higher scales elsewhere (Boyero, 2003).

Our third hypothesis (H3) expected that community metrics and water quality index will depend on an interaction between habitat and typology. However, this hypothesis was not supported. Macroinvertebrate communities are influenced by reach scale factors such as type of substrate, food availability or current velocity (Beisel et al., 1998, Chaves et al., 2005, Collier et al., 1998). However, they are also influenced by larger scale variables mainly driven by changes in altitude, conductivity and temperature (Graça et al., 1989, Pires et al., 2000, Aguiar et al., 2002, Chaves et al., 2005, Sroczynska et al., 2017). Such regional filters can influence species distributions by direct control on species biological traits, or indirectly by affecting the patch structure and size. In our study, lack of interaction among habitat and stream type demonstrates that regional factors affect macroinvertebrate communities by directly controlling their traits and therefore limit their occurrence at a given stream type. Furthermore, smaller scale habitat characteristics affect macroinvertebrates independently on stream type. Such result provides a clear evidence that the effect of stream typology does not depend on the habitats that are present 
in the given stream type and vice versa. This finding also supports a previous study on these streams indicating that larger (regional) scale factors structure benthic communities independently on the habitat scale (Sroczynska et al., 2017).

\section{Implications for the biomonitoring in the intermittent streams}

Previous studies indicated that sampling only the inorganic substrate of the streambed would account for a limited portion of the organisms, ignoring some of the sensitive taxa that could inhabit organic habitats such as wood, leaf litter or macrophytes ( Kay et al., 1999, Chakona et al., 2008, Reid et al., 2010, Leitão et al., 2014). On the other hand, other authors suggest restricting sampling to only mineral substrates, which shelter the most pollution sensitive taxa (Beauger et al., 2006).

In general, the same sampling effort at more heterogenous sites results in higher taxa richness and abundance than at sites with less number of habitats (Kay et al., 1999, Humphries et al., 1996). Our results demonstrated differences among habitats in water quality index, particularly between gravel and organic, depositional habitats (macrophytes/sand/POM). Due to these differences sampling at the reach scale should include previously mentioned habitats, even if they are underrepresented in the sampled stream section. However, sampling protocols should also address different stream typologies.

Habitat with the highest IPtIs index was gravel, following by cobble and boulder, whereas for stream types M-S and M-L typologies had the highest IPtIs score. It demonstrates that these habitats and these typologies host the most sensitive taxa. Our study shows that these two scales shape taxa occurrences independently on each other, what is reflected in water quality index and therefore the next step forward would be to address both scales simultaneously in development of effective biomonitoring programs.

M-S typology hosted the highest number of families with significant IndVal suggesting that this typology is important for many families with less generalistic set of traits. This typology must be carefully addressed in monitoring programs for water quality assessment even at such fine scale.

An important aspect to mention is the potential effect of the preceding dry period on benthic invertebrate assemblages during the wet phase (e.g. Datry, 2012, Bogan et al., 2013; Boersma et al., 2014). In this study we compared the duration of the dry phase in the years preceding the sampling and during the year of sampling in order to ensure that all of the stations had similar dry period (data obtained from public database of the Portuguese Environment Agency http://snirh.apambiente.pt). Unfortunately, only data on limited number of stations ( 7 in the years 1995-2014 and 12 in 2009) was available. However, since all of the stations belong to the same climatic region and they undergo desiccation in relatively the same period of time we assumed similar hydrological patterns in the remaining stations for which data was lacked. Nevertheless, in the future it is necessary to consider preceding dry period, especially when comparing sites among distinct climatic regions.

There is a need for rapid and cost effective strategies for biological assessment of streams and therefore this knowledge helps to understand at which scale sampling protocols should be improved to accurately represent the actual water quality status.

\section{ACKNOWLEDGEMENTS}

K. Sroczyńska holds a $\mathrm{PhD}$ scholarship of the IMPACT project, founded by the Foundation for Science and Technology (FCT) of Portugal (ERA-IWRM/0003/2009). F. Leitão and P. Range were also funded by grants from Fundação para a Ciência e Tecnologia (Reference SFRH/BPD/63935/2009 and SFRH/BPD/69959/2010). The authors acknowledge Agnieszka Baumritter for English review.

Author Contributions: KS analyzed data and wrote the manuscript, FL participated in sampling and contributed to data analysis, IM, $\mathrm{AF}$ and $\mathrm{MC}$ participated in sampling and macroinvertebrate identification, PR provided editorial advice and contributed to data analysis, LC provided editorial advice. 


\section{REFERENCES}

AGUiAR, F. C., FERREIRA, M. T., \& P. PINTO. 2002. Relative influence of environmental variables on macroinvertebrate assemblages from an Iberian basin. Journal of the North American Benthological Society, 21(1): 43-53. DOI: $10.2307 / 1468298$

ALBA-TERCEDOR, J., P. JÁIMEZ-CUÉLLAR, M. ÁLVAREZ, J. AVILÉS, N. BONADA, J. CASAS, A. MELLADO, M. ORTEGA, I. PARDO, N. PRAT, M. RIERADEVALL, S. ROBLES, C. E. SÁINZ-CANTERO, A. SÁNCHEZ-ORTEGA, M. L. SUÁREZ, M. TORO, M. R. VIDAL-ALBARCA, S. VIVAS \& C. ZAMORA-MUÑOZ. 2002. Caracterización del estado ecológico de los ríos mediterráneos ibéricos mediante el índice IBMWP (antes BMWP'). Limnetica, 21(3-4): 175-185. http://hdl.handle.net/2445/32903

ANGRADI, T. R. 1996. Inter-habitat variation in benthic community structure, function, and organic matter storage in 3 Appalachian headwater streams. Journal of the North American Benthological Society, 15(1): 42-63. DOI: 10.2307/1467432

ARMITAGE, P. D. \& I. PARDO. 1995. Impact assessment of regula- tion at the reach level using macroinvertebrate information from mesohabitats. Regulated Rivers Research and Management, 10: 147-158. DOI: 10.1002/ 1099-1085(200011/12)14:16/17<3161::AIDHYP $140>3.0 . C O ; 2-8$

ARMITAGE, P. D. \& C. E. CANNAN. 2000. Annual changes in summer patterns of mesohabitat distribution and associated macroinvertebrate assemblages. Hydrological Processes, 14(16-17): 3161-3179.

BARMUTA, L. A. 1989. Habitat patchiness and macrobenthic community structure in an upland stream in temperate Victoria, Australia. Freshwater Biology, 21(2): 223-236. DOI: 10.1111/j.1365-2427.1989. tb01361.x

BEAUGER, A., N. LAIR, P. REYES-MARCHANT \& J. L. PEIRY. 2006. The distribution of macroinvertebrate assemblages in a reach of the River Allier (France), in relation to riverbed characteristics. Hydrobiologia, 571:
63-76. DOI: 10.1007/s10750-006-0217-x

BEISEL, J., P. USSEGLIO-POLATERA, S. THOMAS \& J. MORETEAU. 1998. Stream community structure in relation to spatial variation: the influence of mesohabitat characteristics, Hydrobiologia, 389: 73-88. DOI: 10.1023/A:1003519429979

BEISEL, J., P. USSEGLIO-POLATERA, S. THOMAS \& J. MORETEAU. 2000. The spatial heterogeneity of a river bottom: a key factor determining macroinvertebrate communities. Springer Netherlands, pp. 163-171. DOI: 10.1007/978-94-011-4164-2_13

BOERSMA, K. S., BOGAN, M. T., HENRICH, B. A. \& D. A. LYTLE. 2014. Invertebrate assemblages of pools in arid-land streams have high functional redundancy and are resistant to severe drying. Freshwater Biology, 59: 491-501. DOI: 10.1111/fwb. 12280

BOGAN, M. T., BOERSMA, K. S. \& D.A. LYTLE. 2013. Flow intermittency alters longitudinal patterns of invertebrate diversity and assemblage composition in an arid-land stream network. Freshwater Biology, 58: 1016-1028. DOI: 10.1111/fwb.12105

BONADA, N., M. RIERADEVALL, N. PRAT \& V. H RESH. 2006. Benthic macroinvertebrate assemblages and macrohabitat connectivity in Mediterranean-climate streams of northern California Benthic macroinvertebrate assemblages and macrohabitat connectivity in Mediterranean-climate streams of northern California. Journal of the North American Benthological Society, 25: 32-43. DOI: 10.1899/08873593(2006)25[32:BMAAMC]2.0.CO;2

BONADA, N., M. RIERADEVALL, H. DALLAS, J. DAVIS, J. DAY \& R. FIGUEROA. 2008. Multi-scale assessment of macroinvertebrate richness and composition in Mediterranean-climate rivers. Freshwater Biology, 53: 772-788. DOI: 10.1111/j.13652427.2007.01940.x

BOYERO, L. 2003. The quantification of local substrate heterogeneity in streams and its significance for macroinvertebrate assemblages. Hydrobiologia , 499(1): 161-168. DOI: 10.1023/A:1026321331092

BROWN, B. L. 2003. Spatial heterogeneity reduces temporal variability in stream insect 
communities. Ecological Letters, 6: 316-325. DOI: 10.1046/j.1461-0248.2003.00431.x.

CHAKONA, A., C. PHIRI, C. H. MAGADZA \& L. BRENDONCK. 2008. The influence of habitat structure and flow permanence on macroinvertebrate assemblages in temporary rivers in northwestern Zimbabwe. Hydrobiologia, 607(1): 199-209. DOI: 10.1007/s10750008-9391-3

CHAVES, M. L., P. M. CHAINHO, J. L. COSTA, N. PRAT \& M. J. COSTA. 2005: Regional and local environmental factors structuring undisturbed benthic macroinvertebrate communities in the Mondego River basin, Portugal. Archive für Hydrobiologie, 163(4): 497-523. DOI: 10.1127/0003-9136/ 2005/0163-0497

CHÍCHARO, L. M. Z., F. LEITÃO, I. MÁXIMO, R. B. HAMADOU, M. MOREIRA DA SILVA. 2009. Caracterização da Qualidade Ecológica da Água das Ribeiras do Algarve- Macroinvertebrados bentónicos como bioindicadores. Relatório de Monitorização Relativo ao ano de 2009. ICCE - International Center for Coastal Ecohydrology, Faro, Portugal.

CID, N., I. VERKAIK, E. M. GARCÍA-ROGER, M. RIERADEVALL, N. BONADA, M. SÁNCHEZ-MONTOYA \& A. BUFFAGNI. 2016. A biological tool to assess flow connectivity in reference temporary streams from the Mediterranean Basin. Science of the Total Environment, 540: 178-190. DOI: 10.1016/j. scitotenv.2015.06.086

CLARKE, K. R. \& R. M. WARWICK. 2001. Change in Marine Communities: An Approach To Statistical Analysis and Interpretation. - 2nd edition PRIMER-E Ltd: Plymouth, U.K.

COBB, D. G., T. D. GALLOWAY \& J. F FLANNAGAN. 1992. Effects of Discharge and Substrate Stability on Density and Species Composition of Stream Insects. Canadian Journal of Fisheries and Aquatic Science, 49: 1788-1795. DOI: 10.1139/f92-198

COLLIER, K. J., R. J. ILCOCK \& A. S. MEREDITH. 1998. Influence of substrate type and physico-chemical conditions on macroinvertebrate faunas and biotic indices of some lowland Waikato, New Zealand, streams. New Zealand Journal of Marine and Freshwater Research, 32: 1-19. DOI: 10.1080/00288330. 1998.9516802

CUMMINS, K. W. \& G. H. LAUFF. 1967. The Influence of Substrate Particle Size on the Microdistribution of Stream Macrobenthos. Hydrobiologia, 34: 145-181. DOI: 10.1007/ BF00141925

DALLAS, H. F. 2007. The effect of biotope-specific sampling for aquatic macroinvertebrates onreference site classification and the identification of environmental predictors in Mpumalanga, South Africa. African Journal of Aquatic Science, 32: 165-173. DOI: 10.2989/ AJAS.2007.32.2.8.205

DATRY, T. 2012. Benthic and hyporheic invertebrate assemblages along a flow intermittence gradient: effects of duration of dry events. Freshwater Biology, 57(3): 563-574. DOI: 10.1111/j.1365-2427.2011.02725.x

DATRY T., R. CORTI, C. CLARET \& M. PHILIPPE. 2011. Flow intermittence controls leaf litter breakdown in a French temporary alluvial river: the "drying memory". Aquatic Science, 73: 471-483. DOI: 10.1007/s00027011-0193-8

DATRY, T, ARSCOTT, D. B. \& S. SABATER. 2013. Recent perspectives on temporary river ecology. Aquatic Science, 73: 453. DOI: 10.1007/s00027-011-0236-1

DEATH, R. G. \& M. J. WINTERBOURN. 1995. Diversity patterns in stream benthic invertebrate communities: the influence of habitat stability. Ecology, 1446-1460. DOI: 10.2307/ 1938147

DE CACERES, M. \& P. LEGENDRE. 2009. Associations between species and groups of sites : indices and statistical inference. Ecology, 90: 3566-3574. DOI: 10.1890/08-1823.1

DUAN, X., Z. WANG \& S. TIAN. 2008. Effect of streambed substrate on macroinvertebrate biodiversity. Frontiers in Environmental Science \& Engineering, 2: 122-128. DOI: 10.1007/s11783-008-0023-y

DUFRENE, M. P. \& P. LEGENDRE. 1997. Species Assemblages and Indicator Species: The need for a Flexible Asymmetrical Approach. Ecological Monographs, 67: 
345-366. DOI: 10.1890/0012-9615(1997)067 [0345:SAAIST]2.0.CO;2

GARCÍA-ROGER, E. M., M. SÁNCHEZ-MONTOYA, R., GÓMEZ, M. L. SUÁREZ, M. R. VIDAL-ABARCA \& J. LATRON. 2011. Do seasonal changes in habitat features influence aquatic macroinvertebrate assemblages in perennial versus temporary Mediterranean streams? Aquatic Science, 73: 567-579. DOI: 10.1007/s00027-011-0218-3

GARCÍA-ROGER, E. M., M. D. M. SÁNCHEZ-MONTOYA, N. CID, S. ERBA, I. KARAOUZAS, I. VERKAIK \& D. DEMARTINI. 2013. Spatial scale effects on taxonomic and biological trait diversity of aquatic macroinvertebrates in Mediterranean streams. Fundamental and Applied Limnology/Archive für Hydrobiologie, 183(2): 89-105. DOI: $10.1127 / 1863-9135 / 2013 / 0429$

GASITH, A. \& H. V. RESH. 1999. Streams in Mediterranean Climate Regions: Abiotic influences and Biotic Responses to Predictable Seasonal Events. Annual Review of Ecology, Evolution, and Systematics, 30: 51-81. DOI: 10.1146/annurev.ecolsys.30.1.51

GRAÇA, M.A.S., D.M. FONSECA \& S.T. CASTRO. 1989. The distribution of macroinvertebrate communities in two Portuguese rivers. Freshwater Biology, 22: 297-308. DOI: 10.1111/j.1365-2427.1989.tb01103.x

HARPER, D. \& M. EVERARD. 1998. Why should the habitat-level approach underpin holistic river survey and management? Aquatic Conservation, 8: 395-413. DOI: 10.1002/ (SICI)1099-0755(199807/08)8:4<395::AIDAQC297>3.0.CO;2-X

HERSHKOVITZ, Y. \& A. GASITH. 2013. Resistance, resilience, and community dynamics in mediterranean-climate streams. Hydrobiologia, 719(1): 59-75. DOI: 10.1007/ s10750-012-1387-3

HUMPHRIES, P., P. E. DAVIES \& M. E. MULCAHY. 1996. Macroinvertebrate assemblages of littoral habitats in the Macquire and Mersey rivers, Tasmania: implications for the management of regulated rivers. $R \& D$ Management, 12: 99-122. DOI: 10.1002/(SICI) 1099-1646(199601)12:1<99::AID-RRR382> 3.0.CO;2-1
INAG. 2008. Manual para a avaliação biológica da qualidade da água em sistemas fluviais segundo a Directiva Quadro da Água - Protocolo de amostragem e análise para os macroinvertebrados bentónicos. Ministério do Ambiente, do Ordenamento do Território e do Desenvolvimento Regional. Instituto da Água. I. P.

INAG. 2009. Critérios para a classificação do estado das massas de água superficiais. Ministério do Ambiente, do Ordenamento do Território e do Desenvolvimento Regional. Instituto da Água. I. P.Internal Report.

JOHNSON, R. K. \& D. HERING. 2010. Spatial congruency of benthic diatom, invertebrate, macrophyte, and fish assemblages in European streams. Ecological Applications, 20(4): 978-992. DOI: $10.1890 / 08-1153.1$

KAY, W. R., M. J. SMITH, A. M. PINDER, J. M. McRAE, J. A. DAVIS \& S. A. HALSE. 1999. Patterns of distribution of macroinvertebrate families in rivers of north-western Australia. Freshwater Biology, 41: 299-316. DOI: 10.1046/j.1365-2427.1999.00432.x

KUBOSOVA, K., K. BRABEC, J. JARKOVSKY \& V. SYROVATKA. 2010. Selection of indicative taxa for river habitats: a case study on benthic macroinvertebrates using indicator species analysis and the random forest methods. Hydrobiologia, 651: 101-114. DOI: 10.1007/s10750-010-0280-1

LEITÃO, F., S. J. HUGHES, N. ATANASOVA, A. FURTADO \& L. CHÍCHARO. 2014. Habitat-oriented sampling of macroinvertebrates affects the determination of ecological status in temporary Mediterranean River Systems. River Research and Applications, 30: 1233-1247. DOI: 10.1002/rra.2800

LEPORI F., PALM, D., BRÄNNÄS, E. \& MALMQVIST B. 2005. Does restoration of structural heterogeneity in streams enhance fish and macroinvertebrate diversity? Ecological Applications, 15: 2060-2071. DOI: 10. 1890/04-1372

LORENZ, A., C. K. FELD \& D. HERING. 2004. Typology of streams in Germany based on benthic invertebrates: Ecoregions, zonation, geology and substrate. Limnologica-Ecology and Management of Inland Waters, 34(4): 379-389. DOI: 10.1016/S0075-9511(04)80007-0 
MACKAY, R. J. 1992. Colonization by lotic macroinvertebrates: a review of processes and patterns. Canadian Journal of Fisheries and Aquatic Science, 49(3): 617-628. DOI: 10.1139/f92-071

MENGE, B. A. \& A. M. OLSON. 1990. Role of scale and environmental factors in regulation of community structure. Trends in Ecology \& Evolution, 5(2): 52-57. DOI: 10.1016/01695347(90)90048-I

MERRITT, R. K. \& K. W. CUMMINS (eds.). 1996. An introduction to the aquatic insects of North America. - 3rd edition Kendall/Hunt Publishers, Dubuque, Iowa, USA.

MIHUC, T. B. 1997. The functional trophic role of lotic primary consumers: generalist versus specialist strategies. Freshwater Biology, 37(2): 455-462. DOI: 10.1046/j.1365-2427. 1997.00175.x

MUNNÉ, A. \& N. PRAT. 2011. Effects of Mediterranean climate annual variability on stream biological quality assessment using macroinvertebrate communities. Ecological Indicators, 11(2): 651-662. DOI: 10.1016/j.ecolind. 2010.09.004

PARDO, I. \& P. D. ARMITAGE. 1997. Species assemblages as descriptors of mesohabitats. Hydrobiologia, 347: 111-128. DOI: 10.1023/ A:1002958412237

PARSONS, M. \& R. NORRIS. 1996. The effect of habitat-specific sampling on biological assessment of water quality using a predictive model. Freshwater Biology, 36(2): 419-434. DOI: 10.1046/j.1365-2427.1996.00088.x

PIRES, A. M., I. G. COWX \& M. M. COELHO. 2000. Benthic macroinvertebrate communities of intermittent streams in the middle reaches of the Guadiana Basin (Portugal). Hydrobiologia, 435(1): 167-175. DOI: 10. 1023/A:1004003726283

POFF, N. L. 1997. Landscape filters and species traits: towards mechanistic understanding and prediction in stream ecology. Journal of the north American Benthological society, 16(2): 391-409. DOI: 10.2307/1468026

PRAT, N., M. RIERADEVALL, C. BARATA \& A. MUNNÉ. 2013. The combined use of metrics of biological quality and biomarkers to detect the effects of reclaimed water on macroinvertebrate assemblages in the lower part of a polluted Mediterranean river (Llobregat River, NE Spain). Ecological indicators, 24: 167-176. DOI: 10.1016/j.ecolind. 2012.06.010

RABENI, C. F \& K. E. GIBBS. 1980. Ordination of deep river invertebrate communities in relation to environmental variables. Hydrobiologia, 74(1): 67-76. DOI: 10.1007/BF00009016 RABENI, C. F., K. E. DOISY \& D. L. GALAT. 2002. Testing the Biological Basis of a Stream Habitat Classification Using Benthic Invertebrates. Ecological Applications, 12: 782-796. DOI: 10.1890/1051-0761(2002)012[0782: TTBBOA]2.0.CO;2

REID, H. E., G. J. BRIERLEY \& I. K. G. BOOTHROYD. 2010. Influence of bed heterogeneity and habitat type on macroinvertebrate uptake in peri-urban streams. International Journal of Sediment Research, 25: 203-220. DOI: 10.1016/S1001-6279(10)60039-X.

RESH, V. H., J. K. JACKSON. 1993. Rapid assessment approaches to biomonitoring using benthic macroinvertebrates. In: Freshwater biomonitoring and benthic macroinvertebrates. D.M. Rosenberg \& V.H. Resh (eds.): 195-233. Chapman and Hall, New York.

RICE, S. P., M. T. GREENWOOD \& C. B. JOYCE. 2001. Macroinvertebrate community changes at coarse sediment recruitment points along two gravel bed rivers. Water Resource Research, 37: 2793-2803. DOI: 10.1029/ 2000WR000079.

ROSI-MARSHALL, E. J., K. L. VALLIS, C. V. BAXTER \& J. M. DAVIS. 2016. Retesting a prediction of the River Continuum Concept: autochthonous versus allochthonous resources in the diets of invertebrates. Freshwater Science, 35(2): 534-543. DOI: 10.1086/686302 SABATER, S., H. GUASCH, I. MUÑOZ \& A. ROMANÍ. 2006. Hydrology, light and the use of organic and inorganic materials as structuring factors of biological communities in Mediterranean streams. Limnetica, 25: 335-348.

SÁNCHEZ-CARMONA, R., L. ENCINA, A. RODRÍGUEZ-RUIZ, M. V. RODRÍGUEZSÁNCHEZ \& C. GRANADO-LORENCIO. 2012. Food web structure in Mediterranean streams: exploring stabilizing forces in these 
ecosystems. Aquatic Ecology, 46(3): 311-324. DOI: $10.1007 / \mathrm{s} 10452-012-9400-5$

SÁNCHEZ-MONTOYA, M. M., T. PUNTI, M. L. SUAREZ, M. D. R. VIDAL-ABARCA, M. RIERADEVALL, J. POQUET \& N. PRAT. 2007. Concordance between ecotypes and macroinvertebrate assemblages in Mediterranean streams. Freshwater Biology, 52(11): 2240-2255. DOI: 10.1111/j.1365-2427.2007. 01826.x

SÁNCHEZ-MONTOYA, M. D. M., M. L. SUÁREZ \& M. R. VIDAL-ABARCA. 2009a: Seasonal and interannual variability of macroinvertebrate reference communities and its influence on bioassessment in different Mediterranean stream types. Fundamental and Applied Limnology/Archive fur Hydrobiologie, 174(4): 353-367. DOI: 10.1127/18639135/2009/0174-0353

SÁNCHEZ-MONTOYA, M. M., M. R. VIDAL-ABARCA, T. PUNTÍ, J. M POQUET, N. PRAT, M. RIERADEVALL \& M. L. SUÁREZ. 2009b. Defining criteria to select reference sites in Mediterranean streams. Hydrobiologia, 619(1): 39-54. DOI: 10.1007/s10750-008-9580-0

SÁNCHEZ-MONTOYA, M. M., M. R. VIDAL-ABARCA \& M. L. SUÁREZ. 2010. Comparing the sensitivity of diverse macroinvertebrate metrics to a multiple stressor gradient in Mediterranean streams and its influence on the assessment of ecological status. Ecological Indicators, 10(4): 896-904. DOI: 10.1016/j.ecolind.2010.01.008

SHELDON, A. L. \& R. A. HAICK. 1981. Habitat selection and association of stream insects: a multivariate analysis. Freshwater Biology, 11(5): 395-403. DOI: 10.1111/j.1365-2427. 1981.tb01272.x

SCHRÖDER, M., J. KIESEL, A. SCHATTMANN, S. C. JÄHNIG, A. W. LORENZ \& S. KRAMM. 2013. Substratum associations of benthic invertebrates in lowland and mountain streams. Ecological Indicators, 30: 178-189. DOI: 10.1016/j.ecolind.2013.02.012

SOUTHWOOD, T. R. E. 1977. Habitat, the templet for ecological strategies? Journal of Animal Ecology, 46: 337-365. DOI: $10.2307 / 3817$
SROCZYŃSKA, K., M. CLARO, A. KRUK, A. WOJTAL-FRANKIEWICZ, P. RANGE \& L. CHÍCHARO. 2017. Indicator macroinvertebrate species in a temporary Mediterranean river: Recognition of patterns in binary assemblage data with a Kohonen artificial neural network. Ecological Indicators, 73: 319-330. DOI: 10.1016/j.ecolind.2016.09.010 STUBBINGTON, R., J. ENGLAND, P. J. WOOD \& C. SEFTON. 2017. Temporary streams in temperate zones: recognizing, monitoring and restoring transitional aquatic-terrestrial ecosystems. WIRES Water, 4:e1223. DOI: 10.1002/wat2.1223.

TOWNSEND, C. R. \& A. G. HILDREW. 1994. Species traits in relation to a habitat templet for river systems. Freshwater Biology, 31: 265-275. DOI: 10.1111/j.1365-2427.1994. tb01740.x

TOWNSEND, C. R., S. DOLEDEC \& M. R. SCARSBROOK. 1997. Species traits in relation to temporal and spatial heterogeneity in streams : a test of habitat templet. Freshwater Biology, 37: 367-387. DOI: 10.1046/j. 1365-2427.1997.00166.x

TRIGO, R. M., D. POZO-VAZQUEZ, T. J. OS-BORN, Y. CASTRO-DIEZ, S. GAMIZ-FORTIS \& M. J. ESTEBAN-PARRA. 2004. North Atlantic Oscillation Influence on precipitation, river flow and water resources in the Iberian Peninsula. International Journal of Climatology, 24: 925-944. DOI: 10.1002/joc. 1048

VANNUCCHI, P. E., M. J. LÓPEZRODRÍGUEZ, J. M. T. DE FIGUEROA \& E. GAINO. 2013. Structure and dynamics of a benthic trophic web in a Mediterranean seasonal stream. Journal of Limnology, 72(3): 51. DOI: 10.4081/jlimnol.2013.e51

VERDONSCHOT, P. F. \& R. C. NIJBOER. 2004. Testing the European stream typology of the Water Framework Directive for macroinvertebrates. Hydrobiologia, 516(1-3): 35-54. DOI: 10.1023/B:HYDR.0000025257. 30311.b7.

WILLIAMS, D. D. 1996. Environmental constraints in temporary fresh waters and their consequences for the insect fauna. Journal of the North American Benthological Society, 
Habitat and typology influence macroinvertebrate communities in temporary streams 553

15: 634-650. DOI: $10.2307 / 1467813$

WINTERBOURN, M. J., J. S. ROUNICK \& B.

COWIE. 1981. Are New Zealand stream ecosystems really different? New Zealand
Journal of Marine and Freshwater Research, 15(3): 321-328. DOI: 10.1080/00288330. 1981.9515927

Con el apoyo de: 